\title{
Antioxidant Activity of Alkaloid Compounds from Litsea cubeba Lour.
}

\section{AMINAH DALIMUNTHE ${ }^{*}$, POPPY ANJELISA ZAITUN HASIBUAN ${ }^{1}$, JANSEN SILALAHI², SITI FATIMAH SINAGA ${ }^{1}$ and DENNY SATRIA ${ }^{3}$}

${ }^{1,2,3}$ Department of Pharmacology, Department of Pharmaceutical Chemistry,

Department of Pharmaceutical Biology, Faculty of Pharmacy,

University of Sumatera Utara, Indonesia.

*Corresponding E-mail: aminahdalimunthe@usu.ac.id

http://dx.doi.org/10.13005/ojc/340270

(Received: November 16, 2017; Accepted: January 10, 2018)

\section{ABSTRACT}

Litsea cubeba (Lour.) heartwood. was extracted by maceration. Ethanol extract was fractionated with liquid-liquid extraction using $n$-hexane, chloroform at $\mathrm{pH} 3,7,9$ and 11 to obtained alkaloid fractions. Isolation of alkaloid compounds were isolated with preparative thin layer chromatography. Antioxidant activity for fractions and isolates were determined with DPPH and ABTS assay. The highest $\mathrm{IC}_{50}$ were given by chloroform fractions at $\mathrm{pH} 7$ and compound III. They $\mathrm{IC}_{50}$ were $23.81 \pm 0.01 ; 3.12 \pm 0.02 \mu \mathrm{g} / \mathrm{mL}$ for DPPH assay and $56.43 \pm 0.06 ; 8.62 \pm 0.02 \mu \mathrm{g} / \mathrm{mL}$ for ABTS assay. Compound III was showed maximum absorbance at $(302.8 ; 280.8 ; 206 \mathrm{~nm})$ and wave number (3286.70; 3109.25; 2939.52; 2835.36; 1589.34; 1462.04; 1365.60; 1246.02; 1018.41; $879.54 \mathrm{~cm}^{-1}$ ) which indicate its an alkaloid compound with hydroxyl, methyl, methylene and methoxy group. The results reveal that alkaloid fractions and compounds of Litsea cubeba heartwood has very strong antioxidant potential.

Keywords: Antioxidant. Litsea cubeba, Heartwood, Alkaloid, Fractions, Compounds.

\section{INTRODUCTION}

Oxidation is an important process (normally) in living organisms, free radicals producing from metabolism pathway process or enviromental sources that interact sustainable with biological system. Reactive species are molecules which have an electronic unstability and most reactive. Reactive oxygen species (ROS) are the biggest sources of primary catalyst which initiate process of oxidation in vivo and in vitro and produce oxidative stress. Oxidative stress products when reactive forms of oxygen are produced faster than they could be safely neutralized with antioxidant mechanisms and/or from a decrease in antioxidant defense. The uncontrolled production of oxygen free radicals and the unrateabled system of antioxidant capability in protection results in the cause of many diseases, such as cancer, diabetes, heart diseases, Alzheimer's, and aging ${ }^{1-6}$. 
Attarasa (Litsea cubeba (Lour,) is a plant from Lauraceae family which contain much essential oils which used as antideppresant, antiinflammation, antioxidant, pesticide, antimicrobial, anticancer and neuro pharmacology ${ }^{3}$. Methanol extract from attarasa fruits showed to be active on HeLa cell lines which cause apoptosis through activation of caspase $3 / 7^{3,4}$. There are more than forty isoquinolin alkaloids that contained in Litsea genus which are active as antibacterial agents against Staphylococcus aureus ((+)-N-(methoxycarbonyl)$\mathrm{N}$-nordicentrin; (+)-N-(methoxycarbonyl)- $\mathrm{N}$ norpredicentrin; (+)-N-(methoxycarbonyl)- $N$ norglaucine $)^{5}$. The heartwoods of Litsea cubeba contained high level of phenolic and flavonoid and found to be active as antioxidant ${ }^{6}$. The aim of this study was to determine antioxidant activity of alkaloid fractions and compounds of Litsea cubeba Lour, heartwood.

\section{EXPERIMENTAL}

\section{Plant and chemicals material}

Fresh heartwood of Litsea cubeba (Lour,) was collected from Balige subdistrict, Sumatera Utara province, Indonesia, Litsea cubeba (Lour,) was identified in Herbarium Medanense, Faculty of Mathematic and Natural Products, University of Sumatera Utara, and the voucher specimen was deposited in herbarium. Chemicals used were distilled water (Bratachem), chloroform (Fulltime), hydrochloric acid (Merck \& Co.), sodium hydroxide (Merck \& Co.), 1,1-diphenyl-2-picrylhydrazyl (DPPH) (Sigma), 2,2'-azino-bis(3-ethylbenzhothiazolinesulphonic acid (ABTS) (Sigma), methanol (Merck \& Co.),

\section{Preparation of Extract, Fractions and Isolates}

The air-dried and powdered heartwoods of Litsea cubeba (Lour,) $(1 \mathrm{~kg})$ were repeatedly macerated with ethanol $96 \%$ ( $3 \times 3 \mathrm{~d}, 7.5 \mathrm{~L})$, The filtrate was evaporated to give a viscous extract ${ }^{7-9}$, Viscous extract was fractionated with $n$-hexane and continue with chloroform at $\mathrm{pH} 3,7,9$ and 11 , Chloroform fraction at $\mathrm{pH} 7$ was fractionated with preparative thin layer chromatography (P-TLC) (Merck) using mobile phase dichlormetane: methanol:ammonia (90:10:1) and sprayed with dragendorff reagent ${ }^{10}$. The alkaloid compounds were analyzed with spectrophotometer UV-Vis
(Shimadzu) and FTIR (Shimadzu).

\section{DPPH radical scavenging activity}

The DPPH assay was tested based on previously method ${ }^{11}, 200 \mu \mathrm{M}$ solution of $\mathrm{DPPH} \bullet$ in methanol was added to various concentrations. After $60 \mathrm{~min}$. absorbance was measured at $516 \mathrm{~nm}$ and percentage of inhibition was calculated by comparing the absorbance values of the control and test samples ${ }^{2,5}$.

\section{ABTS radical anion scavenging activity}

The ABTS radical was produced from reaction between $5 \mathrm{~mL}$ of $14 \mathrm{mM}$ ABTS solution and $5 \mathrm{~mL}$ of $4.9 \mathrm{mM}$ pottasium persulfate $\left(\mathrm{K}_{2} \mathrm{~S}_{2} \mathrm{O}_{8}\right)$ solution, stored in the dark at temperature room stand for $16 \mathrm{~h}$, Before use, solution was diluted with phospate buffer saline (PBS) to obtain an absorbance of $0.700 \pm 0.020$ at $734 \mathrm{~nm}$. The fractions and isolates with various concentrations with $1 \mathrm{~mL}$ of ABTS solution was homogenized and its absorbance was recorded at $734 \mathrm{~nm}$, PBS blanks were run in each assay and all of measurements were done after at least $6 \mathrm{~min}$. Similarly the reaction mixture of standard group were obtained using quercetin, ABTS scavenging ability was expressed as $\mathrm{IC}_{50}(\mu \mathrm{g} / \mathrm{mL})[5]$.

\section{Statistical analysis}

Data was expressed as mean \pm SD which were analyzed using the SPSS 21 software.

\section{RESULTS AND DISCUSSION}

\section{Antiradical activity}

Antiradical activity of the plant was measured in term of hydrogen donating ability using DPPH which is a stable, nitrogen-centered free radical and produces deep purple colour in methanol solution, antioxidants either transfer an electron or a hydrogen atom to DPPH, thus neutralizing its free radical character ${ }^{12}$. Antioxidant assay with DPPH and ABTS which is based on the ability of DPPH and ABTS, the stable free radical, to decolorize in the presence of antioxidants, is a direct and reliable method for determining radical scavenging action ${ }^{13}$ and has been largely used as a quick, reliable and reproducible at in vitro antioxidant acitivity assay ${ }^{14}$. The reducing capacity of compounds could serve as marker of potential 
Table 1: $I_{50}$ value of alkaloid fractions and compounds of Litsea cubeba heartwood with DPPH and ABTS assay (Mean \pm SD, 3 times of replication)

\begin{tabular}{lcc}
\hline Treatment & $\mathrm{IC}_{50}(\mu \mathrm{g} / \mathrm{mL})$ & \\
& $\mathrm{DPPH}$ & $\mathrm{ABTS}$ \\
\hline n-hexane Fraction & $409.76 \pm 0.55$ & $236.15 \pm 0.57$ \\
Chloroform Fraction pH 3 & $92.38 \pm 0.02$ & $114.52 \pm 0.33$ \\
Chloroform Fraction pH 7 & $23.81 \pm 0.01$ & $56.43 \pm 0.06$ \\
Chloroform Fraction pH 9 & $28.63 \pm 0.05$ & $71.73 \pm 0.17$ \\
Chloroform Fraction pH 11 & $103.75 \pm 0.03$ & $190.77 \pm 0.44$ \\
Water Fraction & $146.46 \pm 0.08$ & $149.82 \pm 0.39$ \\
Compound I & $25.92 \pm 0.01$ & $21.45 \pm 0.02$ \\
Compound II & $3.12 \pm 0.02$ & $8.62 \pm 0.02$ \\
Compound III & $29.75 \pm 0.01$ & $19.15 \pm 0.04$ \\
Quercetin & $4.95 \pm 0.01$ & $11.39 \pm 0.12$ \\
\hline
\end{tabular}

$\mathrm{ABTS}^{19}, \mathrm{IC}_{50}$ for each fraction and compound shown in Table 1.

\section{Identification of compounds}

Compounds were isolated from chloroform fraction at $\mathrm{pH} 7$ identification with the aid of spectroscopic methods notably UV-Vis and FTIR spectrophotometer. The UV-Vis spectrum were showed compound I (302.8; 280.8; $206 \mathrm{~nm})$, compound II (282.8; $207.6 \mathrm{~nm})$, compound III (301.8; $281.8 ; 218.8 \mathrm{~nm})$. The FTIR spectrum were showed compound I (3394.72; 2943.37; 2839.22; 1589.34; 1462.04; 1369.46; 1242.16; 1033.85; $\left.871.82 \mathrm{~cm}^{-1}\right)$, compound II (3394.72; 2931.80; 2846.93; 1593.20; 1454.33; 1365.60; 1261.45; 1006.84; $\left.875.68 \mathrm{~cm}^{-1}\right)$, compound III (3286.70; 3109.25; 2939.52; 2835.36; 1589.34; 1462.04; 1365.60; 1246.02; 1018.41; $879.54 \mathrm{~cm}^{-1}$ ). The $\mathrm{O}-\mathrm{H}$ groups were interpreted by wave number between $3000-3500 \mathrm{~cm}^{-1}$ (3394.72 and $3286.70 \mathrm{~cm}^{-1}$ ). The $\mathrm{N}-\mathrm{H}$ group was showed at
$3109.25 \mathrm{~cm}^{-1}$. The $\mathrm{C}-\mathrm{H}$ streching groups were showed at $\left(2800-2950 \mathrm{~cm}^{-1}\right)$ and $\mathrm{C}-\mathrm{H}$ bending groups were showed at $\left(2800-2950 \mathrm{~cm}^{-1}\right)$. Many researchers were reported that alkaloid compounds have major functional groups $\mathrm{O}-\mathrm{H}, \mathrm{N}-\mathrm{H}$ and $\mathrm{C}-\mathrm{H}$ streching and bending groups ${ }^{19,20,21}$.

\section{CONCLUSION}

The result of this study showed that alkaloid fractions and compounds of Litsea cubeba heartwood have antioxidant activity.

\section{ACKNOWLEDGEMENT}

We gratefully thank to Research Center University of Sumatera Utara through Hibah Talenta "Hibah Penelitian Dasar" Research Grant

2017 "No: 5338/UN5.1.R/PPM/2017" for financial support in the study.

\section{REFERENCES}

1. Kinnula, V.L., Crapo, J.D., Superoxide dismutases in malignant cells and human tumors, Free Rad Biol Med., 2004, 36, 718-744.

2. Jamuna, S., Pulsamy, S., Karthika, K., Screening of in vitro antioxidant activity of methanolic leaf and root extracts of
Hypochaeris radicata L. (Asteraceae), J App Pharm Sci., 2012, 2, 149-154.

3. Nagmoti, D.M., Khatri, D.K., Juvekar, P.R., Juvekar, A.R., Antioxidant activity free radical-scavenging potential of Pithecellobium dulce Benth seed extracts, Free Rad Antioxid., 2012, 2, 37-43. 
4. Rackova, L., Oblozinsky, M., Kostalova, D., Kettman, V., Bezakova, L., Free radical scavenging activityand lipoxygenase inhibition of Mahonia aquifolium extract and isoquinoline alkaloids, J Inflam., 2007, 4, 15.

5. Rosidah, Yam, M.F., Sadikun, A., Asmawi, M.Z., Antioxidant potential of Gyunura procumbens, Pharm Bio., 2008, 46, 616-625.

6. Yang, Y.C., Lu, F.H., Wu, J.S., Wu, C.H., Chang, C.J., The protective effect of habitual tea consumption on hypertension, Arch Intern Med., 2004, 164, 1534-1540.

7. Satria, D., Furqan, M., Hadisahputra, S., Rosidah, Combinational effects of ethylacetate extract of Picria fel-terrae Lour. and doxorubicin on T47D breast cancer cells, Int J Pharm Pharm Sci., 2015, 7, 73-76.

8. Anggraeni, R., Hadisahputra, S., Silalahi, J., Satria, D., Combinational effects of ethylacetate extract of Zanthoxylum acanthopodium DC. with doxorubicin on T47D breast cancer cells, Int J PharmTech Res., 2014, 6, 2032-2035.

9. Hasibuan, P.A.Z., Jessy, C., Denny, S., Combination effect of ethylacetate extracts of Plectranthus ambonicius (Lour.) Spreng. with doxorubicin againts T47D breast cancer cells, Int J Pharm Pharm Sci., 2015, 7, 155-159.

10. Atta-ur-Rahman, Atia-tul-Wahab, Sultani, S.Z., Sarfraz, A., Nawaz, Choudhary, M.I., Bisbenzylisoquinoline alkaloids from Cocculus pendulus, Nat Prod Res., 2009, 23 (14), 1265-1273.

11. Satria, D., Silalahi, J., Haro, G., Ilyas, S., Hasibuan, P.A.Z., Antioxidant and antiproliferative activities of an ethylacetate fraction of Picria fel-terrae Lour. Herbs, Asian Pac J Cancer Prev., 2017, 18 (2), 399-403.

12. Jebitta, R., Allwin, J., Antioxidant activity, total phenolic, flavonoid, and anthocyanin contents of Jamun (Syzygium Cumini) pulp powder, Asian J Pharm Clin Res., 2016, 9, 361-363.
13. Pan, Y., Wang, K., Huang, S., Wang, H., Mu, X., He, C., Antioxidant activity of microwaveassisted extract of longan (Dimocarpus longum Lour.) peel, Food Chem., 2008, 106 , 1264-1270.

14. Hasan, M.S., Ahmed, M.I., Mondal, S., Uddin, S.J., Masud, M.M., Sadhu, S.K., Antioxidant, antinociceptive activity and general toxicity study of Dendrophthoe falcata and isolation of quercitin as the major component. Opem., 2006, 6, 355-60.

15. Koleva, I.I., Van Beek, T.A., Linssen, J.P.H., de G root, A., Evstatieva, L.N., Screening of plant extracts for antioxidant activity: a comparative study on three testing methods, Phytochem Anal., 2002, 13, 8-17.

16. Meir, S., Kanner, J., Akiri, B., Hada, S.P., Determination and involvement of aqueous reducing compounds in oxidative defense system of various senescing leaf, $J$ Agricult Food Chem., 1995, 43, 1813-1819.

17. Dalimunthe, A., Suryadi, Satria, D., Phenolic, flavonoid content and antioxidant activities of ethylacetate extract of Litsea cubeba (Lour.) Pers. barks., Der Phar Chem., 2016, 8 (19), 466-468.

18. Shah, A., Singh, T., Rekha, V., In vitro antioxidant properties and total phenolic and flavonoid contents of Rumex vesicaius L., Int J Pharm Pharma Sci., 2015, 7 (7), 81-84.

19. Son, S., Lewis, B.A., Free radical scavenging and antioxidative activity of caffeic acid amide and and ester analogues: structure activity relationship, J. Agric. Food. Chem., 2005, 50 , 468-72.

20. Windono, T., Umar, A., Jenie, Leonardus, B.S.K., Isolation and elucidation of Pyrrolizidine alkaloids from tuber of Gynura pseudo-china (L.) DC, J App Pharm Sci., 2012, 2 (5), 05-09.

21. Shami, A.M.M., Isolation and identification of alkaloids extracted from local plants in Malaysia, Ann Chromatogr Sep Tech., 2016, 2(1), 1016. 